\title{
Environment and Potential Affecting Investment Decision for Accommodation Business: Case of Less Visited Area in Samut Songkhram and Phatthalung Province
}

${ }^{1}$ Krisada Sungkhamanee; ${ }^{2}$ Piyadhida Sungkhamanee

${ }^{1,2}$ Suan Sunandha Rajabhat University, Thailand. Email: krisada.su@ ssru.ac.th; piyadhida.s@gmail.com

\begin{abstract}
Investment decisions have great importance in different sectors of various countries and these decisions are the basis on which the outcomes of the investments are based. However, there might be certain factors that might lead to the incorrect long term and short term investment decisions. In this regard, the current study has been conducted with the core motive to explore the impact casted by the environment and potential factors i.e. salience and overconfidence on the long term investment decisions for accommodation business along with the moderation of a variable i.e. financial literacy. To fulfill this objective, the researcher has collected data from the investors of accommodation businesses in Thailand. The collected data has been subjected to different statistical techniques and tools for analysis purpose and the results have been obtained. The results obtained by the analysis of the collected data indicate that salience and overconfidence have significant impact on the long term investment decision. In addition, the moderating role of financial literacy has also been found as significant in the study. The results suggest that the investors of the accommodation business must consider the aspects of salience and overconfidence before taking any long term investment decision to avoid failure of the investment decision.
\end{abstract}

Keywords: Salience, Overconfidence, Long Term Investment Decisions, Accommodation Business, Financial Literacy

\section{$1 \quad$ Introduction}

Investment decisions are made by the representatives or top management of a firm or an organization as discussed in the conventional theories regarding finance. But actually these decisions are more than that and they also involve the positive or negative attitude of the management of a company (De Vries, Erasmus, \& Gerber, 2017). The traditional finance theories have been criticized in many ways. In this regard, Yalcin, Tatoglu, and Zaim (2016) has criticized the two main assumptions of these theories. The first assumption in this regard is that the behavior shown by humans is completely rational while making investment decisions as per utility theory. In the same way, the other assumption that has been criticized is that the financial markets are also rational as they show correct prices. According to the international capital pricing model which had its foundations in traditional portfolio theory suggested that the investments must be made in those assets that possess high risk adjusted returns (Lintner, 1975; Sharpe, 1964). But the investors do not invest in this way and act rationally ignoring all the benefits associated with diversification (Ahearne, Griever, \& Warnock, 2004; Chan, Covrig, \& Ng, 2005). This might be due to various reasons such as salience bias or familiarity effect. These aspects have been studied by various researchers in the past (Barber \& Odean, 2001; Barberis \& Xiong, 2009; Choi, Laibson, Madrian, \& Metrick, 2004; Lee, Liu, Roll, \& Subrahmanyam, 2004; Thaler \& Sunstein, 2009 Baranova, \& Bogatyreva, 2019). Salience effect is an important cognitive heuristic effect among all the heuristics as it has been considered to have a stronger effect on the decision making. In addition, its importance is based on the fact that the investment decision makers face this issue more as compared to others (Hirshleifer, 2001; Yalcin et al., 2016). Another factor that might impact the decision making process of investment is over confidence in context of the investment returns. Moreover, the financial literacy might also play role in the precision of the financial or investment decision making process. 
Figure 1: Public Sector Net Investment (economicshelp)

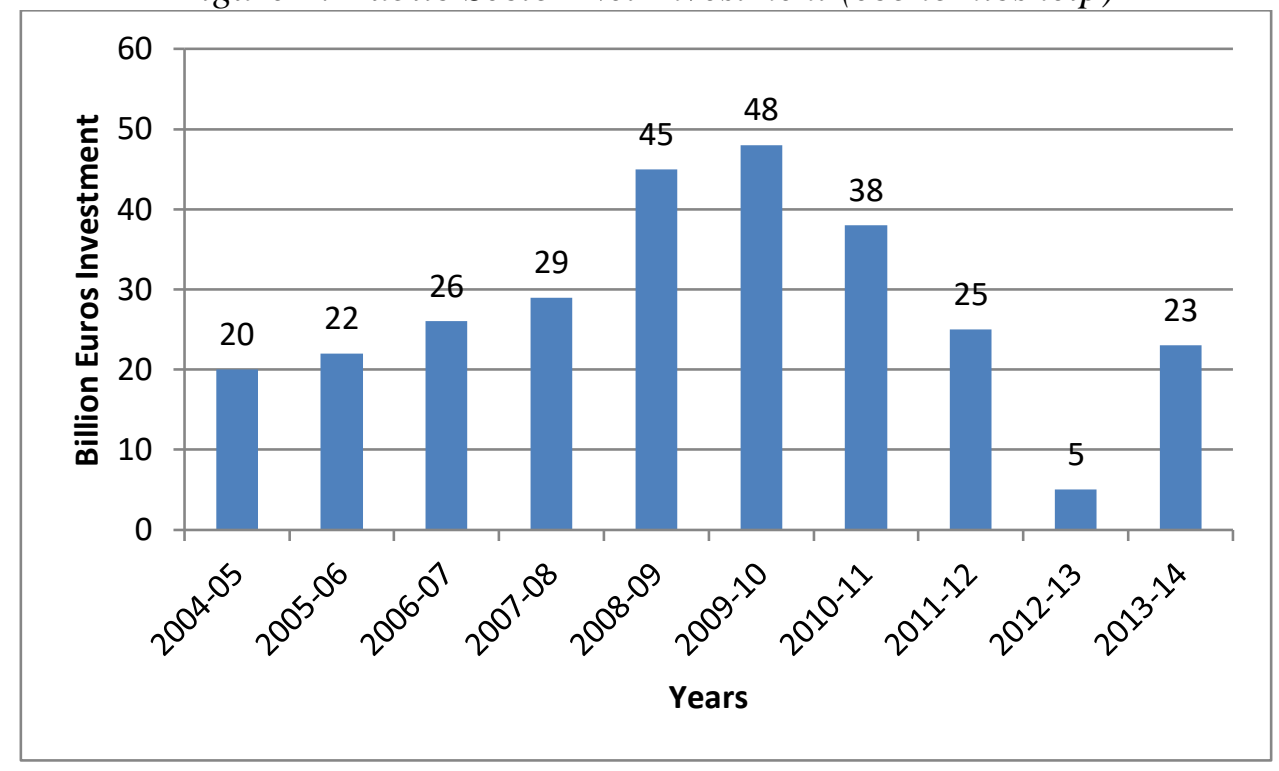

Investment decisions are the most important decisions for the investors of different organizations and companies but these decisions might be made wrongly due to several reasons such as salience and overconfidence. In addition, if the financial knowledge or information regarding the markets might also impact the decision making positively or negatively. In the past, studies have shown the impact of different factors on the investment decision making but there are no studies that have taken the environmental and potential factors i.e. salience and overconfidence into consideration. In addition, this study has not been conducted in context of the accommodation business in the less visited areas of Samut Songkhram and Phatthalung Province. This study has thus been conducted to fulfill these gaps and has the following objectives;

- To analyze the impact of the environment factor i.e. salience on the long term investment decision for accommodation business

- To analyze the impact of the potential factor i.e. overconfidence on the long term investment decision for accommodation business

- To determine the moderating role of financial literacy in the relationship between salience and long term investment decision

- To determine the moderating role of financial literacy in the relationship between overconfidence and long term investment decision

This study will be very much beneficial for the investors that have to make certain investment decisions frequently to consider the salience and overconfidence aspects while making decisions and also to enhance their literacy regarding finance.

Table 1: Public Sector Net Investment (\% of GDP) (economicshelp)

\begin{tabular}{ll}
\hline Years & \begin{tabular}{l} 
Public $\quad \begin{array}{c}\text { Sector Net } \\
\text { Investment (\% of GDP) }\end{array}$ \\
\hline $2008-09$
\end{tabular} \\
$2009-10$ & $3.2 \%$ \\
$2010-11$ & $2.5 \%$ \\
$2011-12$ & $2 \%$ \\
$2012-13$ & $1.5 \%$ \\
$2013-14$ & $1.4 \%$ \\
\hline
\end{tabular}

\section{Literature Review}

\subsection{Impact of Salience on Long Term Investment Decisions}

In the past studies, salience heuristics have been studied regarding the investment decision making by different researchers. According to Shiloh, 
Salton, and Sharabi (2002), heuristics means the rapid or prompt automatic systems which can be used to make the calculations simple (Tversky \& Kahneman, 1974). In the same way, these heuristics are also taken as the rule of thumb which also leads towards the better decision making process (Aronson, 1999; Mishra, 2014). However, it has been found out that the use of these heuristics might not be well received in some cases and lead towards the pathetic mistakes during decision making process. As far as salience is concerned, it is also called as familiarity bias (Huberman, 2001). There are different other aspects such as familiarity, availability, home bias etc. that can be used in place of salience bias and all of them come under the umbrella of salience. The basic idea behind this bias in relation with the investment decision making is that the investors tend to invest in the stocks that are familiar to them because they think that investing in the unknown stocks might be riskier as compared to the familiar stocks (Merton, 1987).(Razzaq, Maqbool, \& Hameed, 2019) In the same way, another study suggested that the investors will tend to go into the situation where they will feel that they know the outcomes and will avoid those investments in which the outcomes are unknown and the investors feel unacquainted (Heath \& Tversky, 1991). It was also indicated that the investors might let go the benefits of diversification and will invest in those companies or projects with which they are already familiar. But in this condition, the benefits of diversification act as the opportunity cost. Fox and Tversky (1995) found out that when there are two choices in front of an investor and both of them are riskier, then the investor will choose that one which will be familiar or salient. This happen mostly when the investors have to make really fast decisions. The process of choosing the best option is very tiresome and takes more time therefore the investors go for the familiar choice to avoid the pressure of decision making (Yalcin et al., 2016). The salience bias of the investors increase the confidence and optimism of the investors as they think that they have made the right decision by selecting the familiar choice (Barber, Odean, \& Zheng, 2005). A Swiss study suggested that the respondents tend to cho0se those products that are easier to understand and this behavior is also because of the salience bias (Wang, Keller, \& Siegrist, 2011). Thus based on this decision, the following hypothesis can be generated;

H 1: Salience has significant impact on long term investment decisions

\subsection{Impact of Overconfidence on Long Term Investment Decisions}

The impact of overconfidence on the investment decision making has been considered in the past similar studies. According to De Bondt and Thaler (1985), the most important behavioral factor that is required in order to understand the trading puzzle is overconfidence. Overconfidence has been found to have an important factor that leads towards the high trading levels. Overconfident investors are found to have made better investment decisions and and trade more as compared to the rational decision makers (Odean, 1998). In other words, it can be stated that if the investment decisions are made overconfidently, it will result in more trade and less expected utility. A relevant theory was presented regarding overconfidence of investors which showed that the self attribution bias due to investment outcomes is the reason behind the overconfidence in investors (Daniel, Hirshleifer, \& Subrahmanyam, 1998). This theory showed that the investors react more towards the private information as compared to the public information. Another study took this aspect to the genders and indicated that men trade more excessively than women because men tend to be more overconfident. This result was obtained by the analysis of the data collected from more than 35, 000 households for seven years and the results suggested that the level of trade by men is 455 higher as compared to women (Gervais \& Odean, 2001). A model was developed according to which when an investor starts trading, he or she is not overconfident but it increases over time and after the trading is over the level of overconfidence falls ultimately. It was also shown by the model that the investors with less experience will have more overconfidence as compared to those having more 
experience (Montier \& Strategy, 2002). Thus, it can be concluded from the discussion that overconfidence might impact the investment decision making and thus it can be hypothesized that;

$\mathrm{H}$ 2: Overconfidence has significant impact on long term investment decisions

\subsection{Moderating Role of Financial Literacy}

Financial literacy is the education or basic understanding about the basics of finance and money, regarding its management and earning process. In addition, the principles of investment are also included in the financial literacy (Giesler \& Veresiu, 2014). Financial literacy is different on the basis of gender, work experience, education, occupation etc. In other words, it has been found out that males have higher level of financial literacy as compared to females. In the same way, the people with more work experience have more financial literacy as compared to the people having less work experience and same goes for rank, occupation, education etc. (Chen \& Volpe, 1998). Studies have suggested that financial literacy has significant and positive impact on the investment decision making. It can be elaborated in such a way that the people with high financial literacy have more knowledge about different techniques and tools used for making investment decisions. They might use finance related publications that contain financial information about different projects but the people with less financial literacy depend upon the advice of other people. The investors with less financial literacy might get victim of salience and overconfidence and thus they might make wrong investment decisions (Al-Tamimi, 2009). Thus it can be stated that financial literacy might have the moderating impact on the relationship between salience and overconfidence; and investment decisions. Thus it can be hypothesized that;

$\mathrm{H}$ 3(a): Financial literacy has significant moderating impact on the relationship between salience and long term investment decisions

$\mathrm{H}$ 3(b): Financial literacy has significant moderating impact on the relationship between overconfidence and long term investment decisions

\subsection{Theoretical Framework}

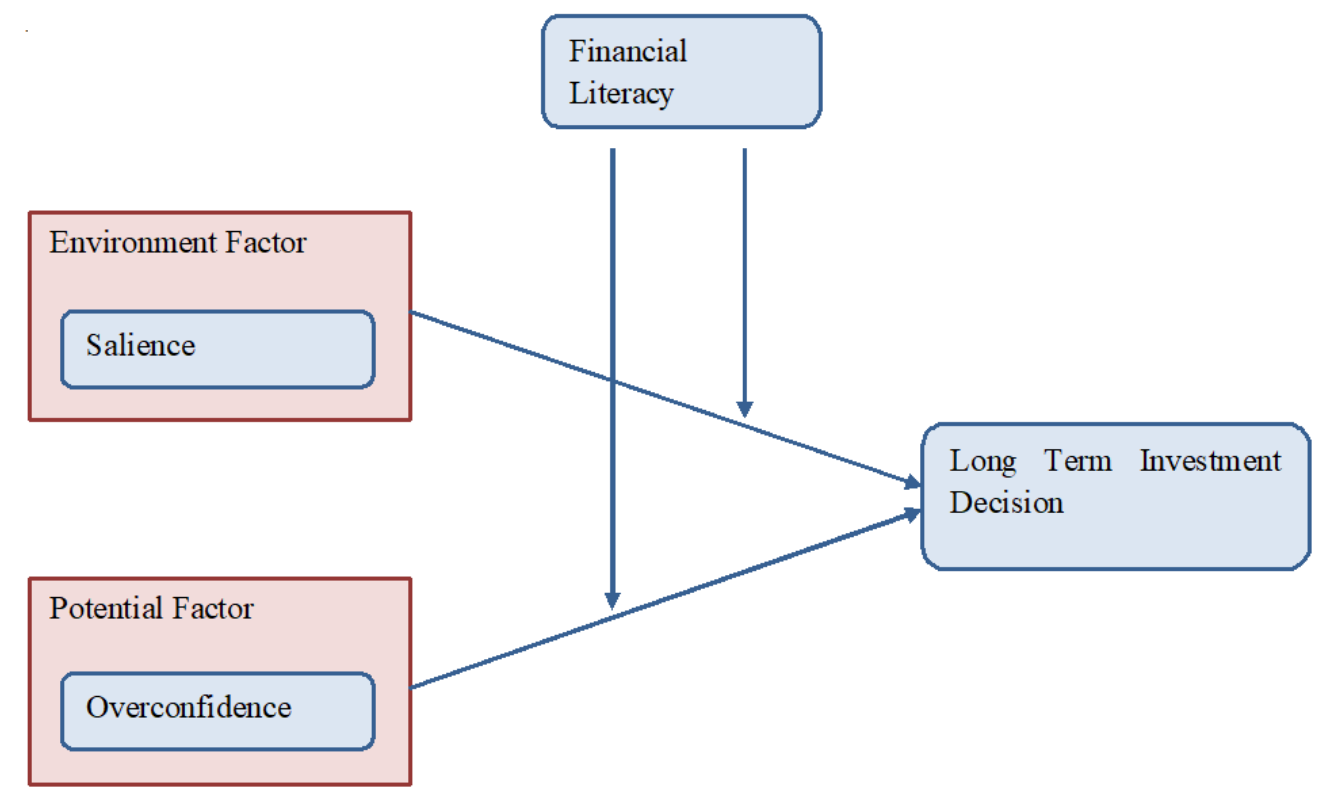

\section{$3 \quad$ Methodology}

This section includes the details about the data collection process and sampling of the population. Besides, the measurement items regarding the variables of the study taken from the past studies have also been discussed in this section.

\subsection{Data}

The purpose of the current study was to explore the impact casted by the environment and potential factors i.e. salience and overconfidence on the long term investment decisions for accommodation business along with the moderation of a variable 
i.e. financial literacy. In context of this objective, the researcher has considered the investors of accommodation business as the population of the study and the sample has been selected from the population through purposive sampling technique so that the right information from the right people can be obtained that is useful for the study. In this regard, 400 questionnaires were obtained from the respondents from which only 375 were selected as reliable for analysis purpose. The questionnaire was designed carefully to collect all the relative information and all the ethical aspects were also considered in regard of questionnaire administration.

\subsection{Measures}

In this regard, salience has five items for measurement and the sample item among them is "A company's stock which is often in the media with favorable news coverage should be preferred when investing" (Yalcin et al., 2016). Similarly, overconfidence has five six for measurement purposes and the sample item of this construct is "How much control do you believe you have in picking investments that will outperform the market". The items for these constructs have been developed by a researcher in the past study (Pompian, 2008). The long term investment decision has three measurement items, developed by a study in the past (Mayfield, Perdue, \& Wooten, 2008). A sample item is "I intend to manage my portfolio for maximum gross return rather than tax and cost efficiency". In the last, the moderator, financial literacy is measured by using five items. These items have been taken from the inspiration of a past research (Van Rooij, Lusardi, \& Alessie, 2011). A sample item is "Suppose you had Rs.100 in a savings account and the interest rate was $2 \%$ per year. After 5 years, how much do you think you would have in the account if you left the money to grow?" It must be noted that these items have been measured on the basis of five point Likert scales that ranges from 1 to 5, where 1 means to strongly disagree and 5 means to strongly agree.

\subsection{Data Analysis}

The collected data has been analyzed by using statistical analysis software i.e. SPSS and AMOS, by the researcher. Various tests such as confirmatory factor analysis, structural equation modeling etc. have been applied for analysis purpose.

\section{$4 \quad$ Results and Analysis \\ 4.1 Demographics}

The demographics of gender suggest that there were $55.5 \%$ males and $44.5 \%$ females included in the total respondents i.e. 375 . In the same way, the demographics of age indicate that $39.5 \%$ (maximum) respondents had the age of 25 to 35 years while $4 \%$ (minimum) respondents had the age more than 45 years. As far as experience is concerned, most of the respondents i.e. almost $77 \%$ were having a good experience i.e. 2 to 8 years in investment decisions.

\subsection{Descriptive Statistics}

The descriptive statistics of the variables of the study presented in table 1 indicate it clearly that the range of minimum to maximum values is 1 to 5 which is the range of the Five point Likert scale used by the researcher. Moreover, the data values are skewed in such a way that normal distribution is evident.

Table 2: Descriptive Statistics

\begin{tabular}{llllllll}
\hline & $\mathrm{N}$ & \multicolumn{2}{c}{ Minimum } & Maximum & Mean & \multicolumn{3}{c}{ Std. Deviation Skewness } \\
\cline { 2 - 7 } & Statistic & Statistic & Statistic & Statistic & Statistic & Statistic & Std. Error \\
\hline Salience & 375 & 1.00 & 5.00 & 3.2938 & 1.02450 & -.238 & .126 \\
OverConf & 375 & 1.00 & 5.00 & 3.4126 & 1.01132 & -.402 & .126 \\
FinanLit & 375 & 1.00 & 5.28 & 3.4799 & 1.10224 & -.561 & .126 \\
LTInvestD & 375 & 1.00 & 5.00 & 3.5911 & 1.11800 & -.583 & .126 \\
Valid N (listwise) 375 & & & & & & \\
\hline
\end{tabular}




\subsection{KMO and Bartlett's Test}

The KMO and Bartlett's tests are used to estimate the adequacy of the collected data regarding the indicators associated with the variables. The results of KMO and Bartlett's test indicate that the collected data is sufficient for the study and is valid to be used.

Table 3: KMO and Bartlett's Test

\begin{tabular}{lll}
\hline Kaiser-Meyer-Olkin Measure of Sampling Adequacy. & .937 \\
Bartlett's Test of Sphericity & Approx. Chi-Square & 6469.485 \\
& df & 171 \\
& Sig. & .000 \\
\hline
\end{tabular}

\subsection{Rotated Component Matrix}

The results of rotated component matrix have been presented in the table 3, according to which the factor loading values of all the indicators of different variables of the study are greater than 0.7 .
Therefore, it can be suggested that the no cross loading is present and all the indicators contribute in the estimation of the variable.

Table 4: Rotated Component Matrix ${ }^{\mathrm{a}}$

\begin{tabular}{|c|c|c|c|c|}
\hline & Comp & & & \\
\hline & $\overline{1}$ & 2 & 3 & 4 \\
\hline$\overline{\text { SA1 }}$ & & .813 & & \\
\hline $\mathrm{SA} 2$ & & .869 & & \\
\hline SA3 & & .827 & & \\
\hline SA4 & & .811 & & \\
\hline SA5 & & .811 & & \\
\hline OC1 & .848 & & & \\
\hline OC2 & .776 & & & \\
\hline OC3 & .753 & & & \\
\hline OC4 & .835 & & & \\
\hline OC5 & .822 & & & \\
\hline OC6 & .856 & & & \\
\hline FL1 & & & & .853 \\
\hline FL2 & & & & .853 \\
\hline FL3 & & & & .843 \\
\hline ID1 & & & .762 & \\
\hline ID2 & & & .813 & \\
\hline ID3 & & & .857 & \\
\hline ID4 & & & .845 & \\
\hline ID5 & & & .830 & \\
\hline
\end{tabular}

\subsection{Convergent and Discriminant Validity}

The validity of constructs can be identified by using the convergent and discriminant validity in the study. The results associated with these validities have been shown in table 4 which suggests that the constructs of the study are valid to be used for analysis (Al-Nsour, 2020; Al Zoubi \& Al Khamaiseh, 2019; Alamirew \& Leykun, 2020; Alghizzawi \& Masruki, 2019; Amadasun, 2020; Amin, Chen, \& Huang, 2018; Anwana, Udo, \& 
Affia, 2019; Asim \& Kumar, 2018; Asokan, 2020;

Hameed, Basheer, Iqbal, Anwar, \& Ahmad, 2018;

Ul-Hameed, Mohammad, \& Shahar, 2018)

Table 5: Convergent and Discriminant Validity

\begin{tabular}{lllllllll}
\hline & CR & AVE & MSV & MaxR(H) & FL & SA & OC & ID \\
\hline FL & 0.925 & 0.804 & 0.321 & 0.929 & 0.897 & & & \\
SA & 0.933 & 0.735 & 0.320 & 0.965 & 0.531 & 0.857 & & \\
OC & 0.947 & 0.749 & 0.321 & 0.980 & 0.567 & 0.566 & 0.866 & \\
ID & 0.928 & 0.719 & 0.311 & 0.984 & 0.502 & 0.487 & 0.558 & 0.848 \\
\hline
\end{tabular}

\subsection{Confirmatory Factor Analysis}

The confirmatory factor analysis results have been reported in table 5 . The observed values along with the threshold values for different indicators of CFA have been shown. As all observed values are within the threshold range thus it can be stated that the model is fit for the study.

Table 6: Model Fit Indices

\begin{tabular}{llllll}
\hline CFA Indicators & CMIN/DF & GFI & IFI & CFI & RMSEA \\
\hline Threshold Value & $\leq 3$ & $\geq 0.80$ & $\geq 0.90$ & $\geq 0.90$ & $\leq 0.08$ \\
Observed Value & 1.945 & 0.927 & 0.979 & 0.979 & 0.050 \\
\hline
\end{tabular}

Figure 2: CFA

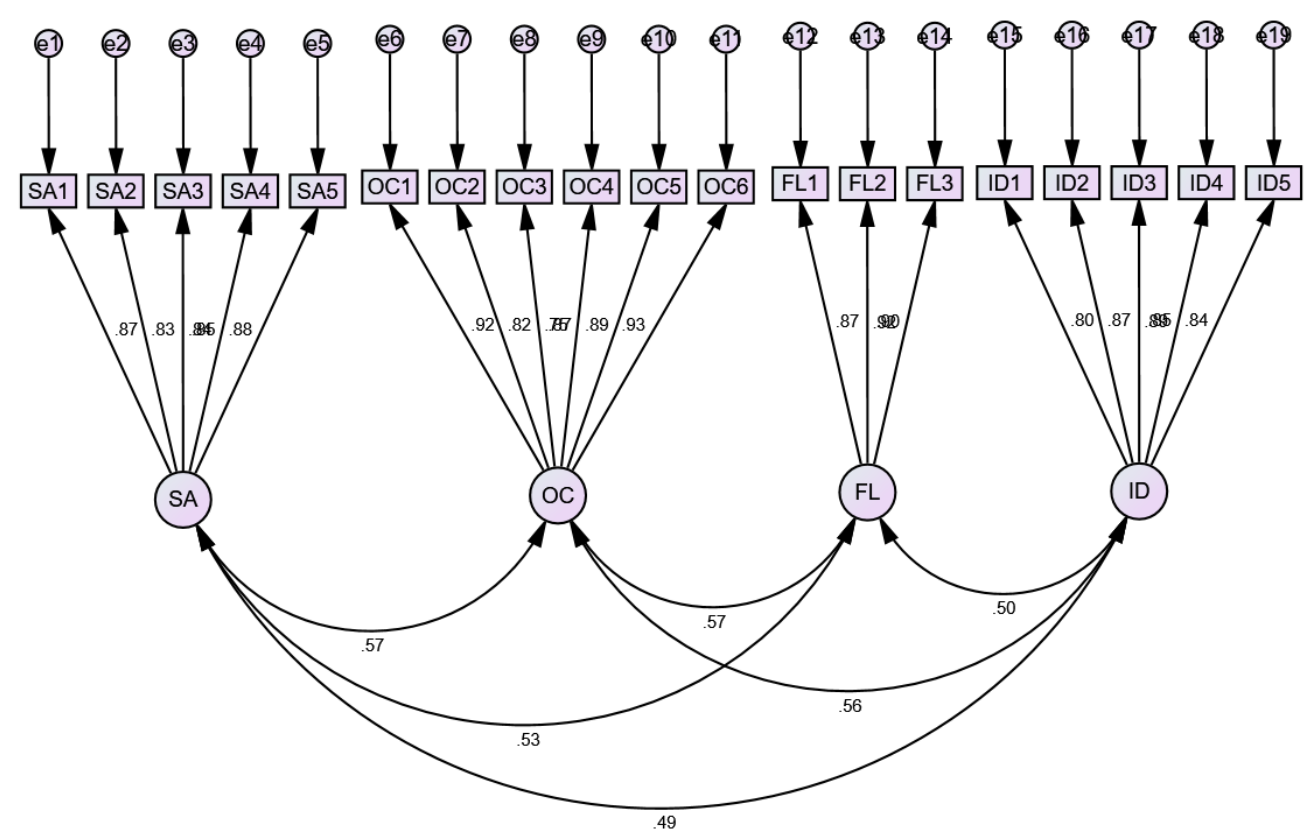

\subsection{Structural Equation Modeling}

As per the results of SEM, reported in table 6, it is evident that both salience and overconfidence have significant imapct on the long term investment decision. In other words, the long term investment decisions can be improved by $24 \%$ and $40.1 \%$

www.psychologyandeducation.net respectively by reducing the impacts of salience and overconfidence by one percent. In the similar fashion, the moderating role of financial literacy has also been found as significant in both cases i.e. salience and overconfidence. 
Table 7: Structural Equation Modeling

\begin{tabular}{lllllll}
\hline & & & Estimate & S.E. & C.R. & P \\
\hline LTInvestD & $<---$ & Salience & .240 & .056 & 4.667 & $* * *$ \\
LTInvestD & $<---$ & OverConf & .401 & .057 & 7.815 & $* * *$ \\
& & & Estimate & S.E. & C.R. & P \\
ZLTInvestD & $<---$ & SAxFL_Int1 & .264 & .046 & 5.549 & $* * *$ \\
ZLTInvestD & $<---$ & ocxFL_Int2 & .147 & .042 & 3.100 & .002 \\
\hline
\end{tabular}

Figure 3: SEM
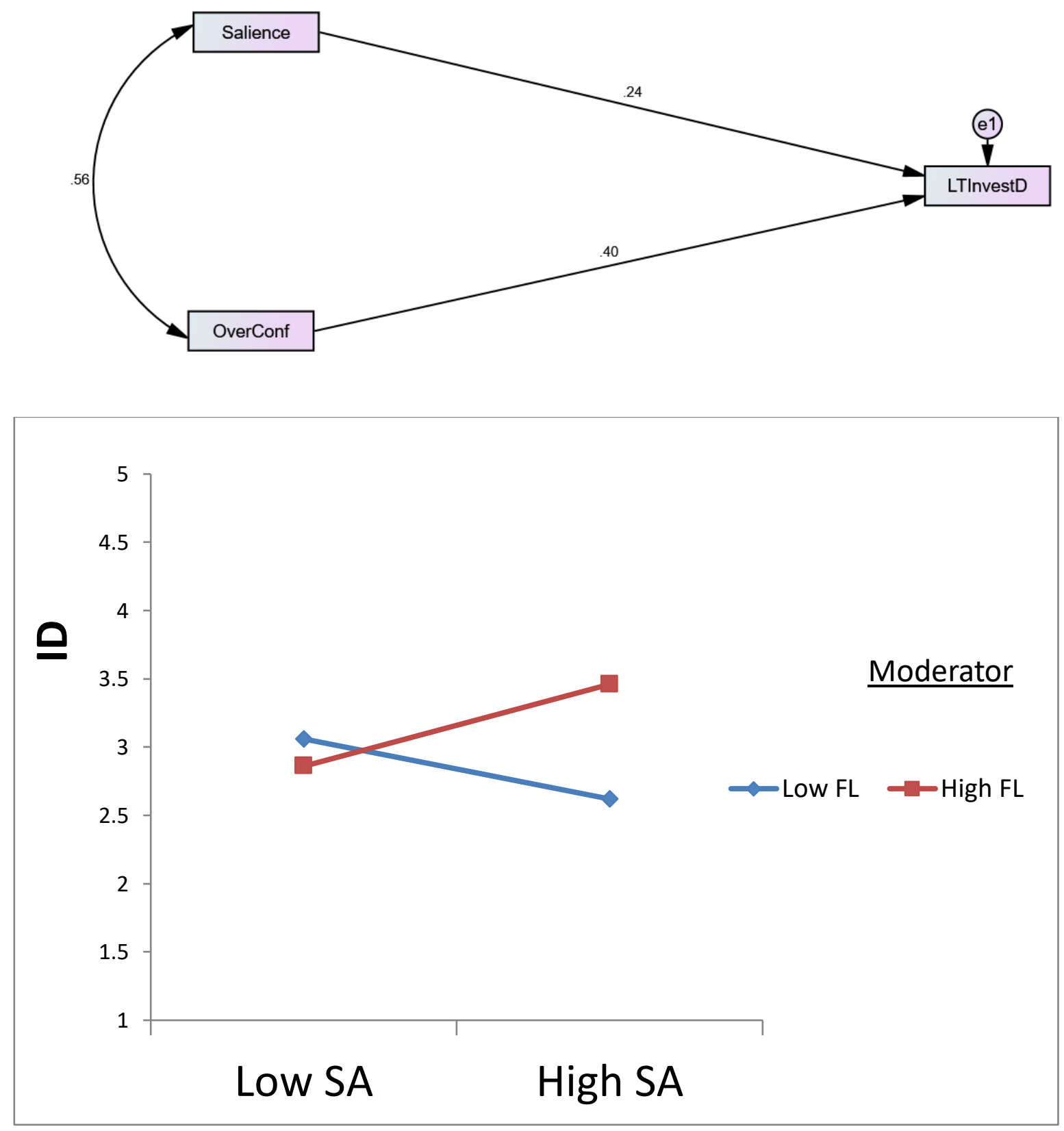


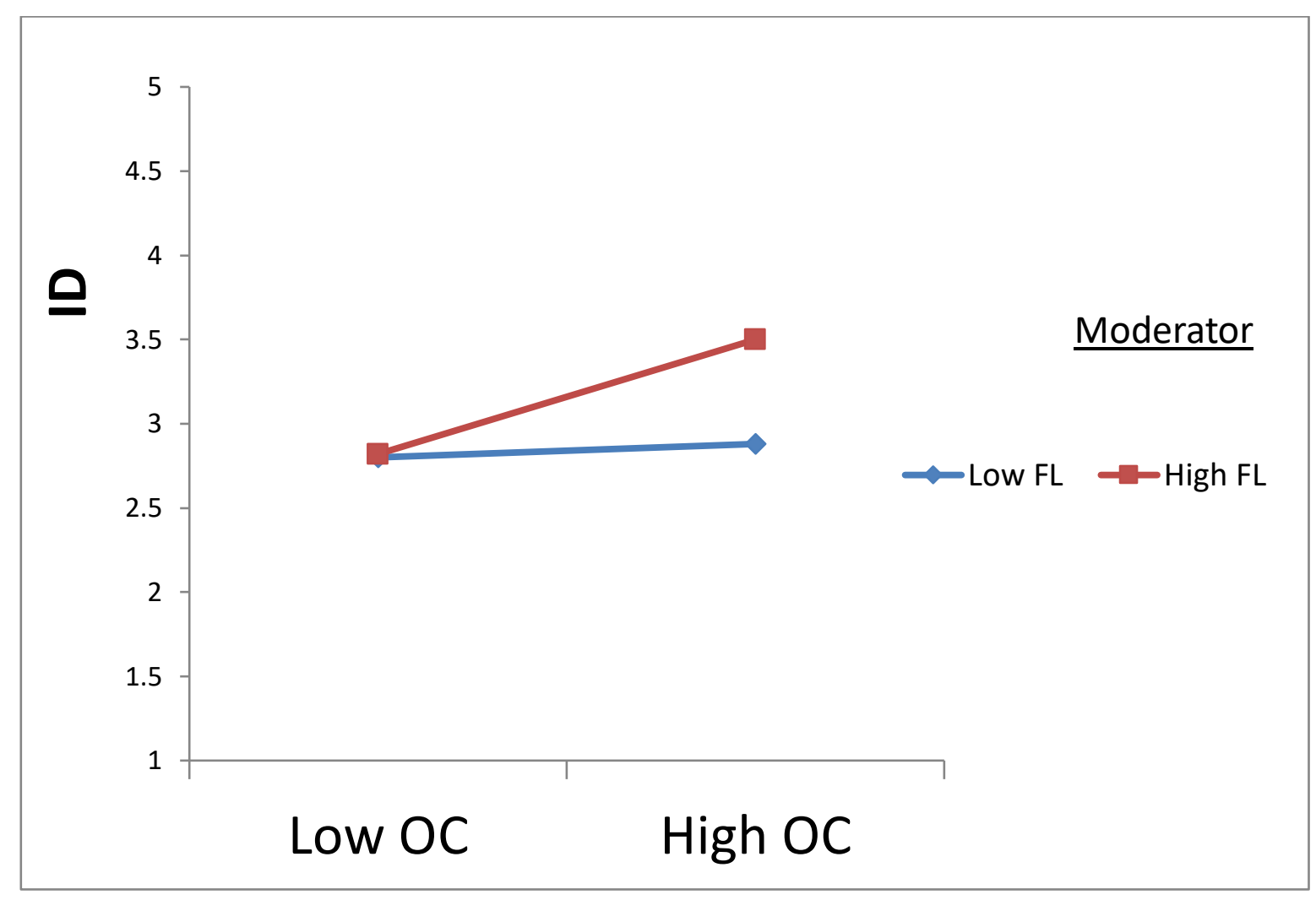

\section{Discussion and Conclusion}

\section{Discussion}

This study was designed in such a way that the impact casted by salience and overconfidence on the long term investment decisions can be explored along with the moderating role of financial literacy. In this regard, different hypotheses were drawn based on the review of the literature. These hypotheses have been tested and verified by the collection of appropriate data and the application of different statistical analysis techniques and tools. The first hypothesis suggested that salience has significant impact on long term investment decision. This hypothesis has been accepted as per the results. Those investment decisions are better that are free from salience bias. This result is presented by another past study (Majoch, Hoepner, \& Hebb, 2017). The second hypothesis was that overconfidence has significant impact on the long term investment decision and this hypothesis has also been accepted in the study. Overconfidence might lead towards wrong investment decisions especially in long term. This result is also in accordance with the past literature (Betzer, van den Bongard, Theissen, \& Volkmann, 2019). Moreover, the next hypotheses were regarding the significant moderating role of financial literacy and these hypotheses have also been accepted in the study. The basic education and information about finance might result in better investment decisions. These results are also consistent with the similar past studies (Garang, 2016).

\section{Conclusion}

The results obtained by the analysis of the collected data indicate that salience and overconfidence have significant impact on the long term investment decision. In addition, the moderating role of financial literacy has also been found as significant in the study. The results obtained from the analysis suggest that the investors of the accommodation business must consider the aspects of salience and overconfidence before taking any long term investment decision as the decision taken under salience bias and over confidence might lead to failure of the investment. The investors must also acquire financial literacy to have the basic knowledge about the basic aspects regarding finance that will be very helpful in taking the right investment decisions. 


\subsection{Implications and Limitations}

The current study has the theoretical implication that the researchers and authors will find the study useful in context of the factors impacting investment decisions. They can use the material of the study for further research or as literature. In addition, the practical implications are for the accommodation business investors who can get assistance in considering the aspects of salience and overconfidence before taking any long term investment decision as the decision taken under salience bias and over confidence might lead to failure of the investment. The investors must also acquire financial literacy to have the basic knowledge about the basic aspects regarding finance that will be very helpful in taking the right investment decisions.

The researchers might also consider the sector other than accommodation business in which the investment decisions have great importance. In addition, the sample size must be increased and the sampling technique must be improved.

\section{REFERENCES}

[1] Ahearne, A. G., Griever, W. L., \& Warnock, F. E. (2004). Information costs and home bias: an analysis of US holdings of foreign equities. Journal of international economics, 62(2), 313-336.

[2] Al-Nsour, I. A. (2020). Effect of Brand Enhancement on Buying Behavior towards the Sport Sponsorship Companies in Riyadh, KSA. International Journal of Business, Economics and Management, 7(2), 110-119. doi: 10.18488/journal.62.2020.72.110.119

[3] Al-Tamimi, H. A. H. (2009). Financial literacy and investment decisions of UAE investors. The Journal of Risk Finance.

[4] Al Zoubi, S. M., \& Al Khamaiseh, A. Z. (2019). A critical study of william shakespeare's king lear: Plot and structure. International Journal of English Language and Literature Studies, 8(1), 14-18. doi: 10.18488/journal.23.2019.81.14.18
[5] Alamirew, A., \& Leykun, F. (2020). Determinant of tax revenue effort in SubSaharan African countries: A stochastic frontier analysis. International Journal of Sustainable Development \& World Policy, 9(1), 47-71. doi: 10.18488/journal.26.2020.91.47.71

[6] Alghizzawi, M. A., \& Masruki, R. B. (2019). Organizational commitment and the readiness towards accrual accounting: The moderating role of job satisfaction. International Journal of Asian Social Science, 9(2), 169-178. doi: 10.18488/journal.1.2019.92.169.178

[7] Amadasun, S. (2020). Social Work Services for Persons with Disabilities in Nigeria: A Qualitative Inquiry. International Journal of Social Sciences Perspectives, 6(2), 59-67. doi: https://doi.org/10.33094/7.2017.2020.62.5 9.67

[8] Amin, A., Chen, Y., \& Huang, S. (2018). Personal Income Tax and Economic Growth: A Comparative Study Between China and Pakistan. Asian Journal of Economic Modelling, 6(1), 65-73. doi: 10.18488/journal.8.2018.61.65.73

[9] Anwana, E. O., Udo, A. B., \& Affia, S. E. (2019). Agricultural Value Added, Governance and Insecurity in Nigeria: An Empirical Analysis. Asian Business Research Journal, 4, 1-9. doi: https://doi.org/10.20448/journal.518.2019. 41.1 .9

[10] Aronson, E. (1999). The social animal. New York: Worth. vol, 70, 416.

[11] Asim, A., \& Kumar, N. (2018). Service quality in higher education: Expectations and perceptions of students. Asian Journal of Contemporary Education, 2(2), 70-83. doi: 10.18488/journal.137.2018.22.70.83

[12] Asokan, D. (2020). Impact of Trust Aspects and Value Co-Creation as Mediation on Purchase Intention in Social Networking Context. American Journal of Social 
Sciences and Humanities, 5(2), 221-229. doi: 10.20448/801.52.221.229.

[13] Barber, B. M., \& Odean, T. (2001). Boys will be boys: Gender, overconfidence, and common stock investment. The quarterly journal of economics, 116(1), 261-292.

[14] Barber, B. M., Odean, T., \& Zheng, L. (2005). Out of sight, out of mind: The effects of expenses on mutual fund flows. The Journal of Business, 78(6), 2095-2120.

[15] Barberis, N., \& Xiong, W. (2009). What drives the disposition effect? An analysis of a long-standing preference-based explanation. the Journal of Finance, 64(2), 751-784.

[16] Baranova, N. \& Bogatyreva, L. (2019). the study of the dynamic series of financial indicators of enterprises in the hotel sector. International Journal of business tourism and applied sciences. 7(2), 47-54

[17] Betzer, A., van den Bongard, I., Theissen, E., \& Volkmann, C. (2019). All Is Not Lost that Is Delayed: Overconfidence and Investment Decisions. Paper presented at the Paris December 2017 Finance Meeting EUROFIDAI-AFFI.

[18] Chan, K., Covrig, V., \& Ng, L. (2005). What determines the domestic bias and foreign bias? Evidence from mutual fund equity allocations worldwide. The Journal of Finance, 60(3), 1495-1534.

[19] Chen, H., \& Volpe, R. P. (1998). An analysis of personal financial literacy among college students. Financial services review, 7(2), 107-128.

[20] Choi, J. J., Laibson, D., Madrian, B. C., \& Metrick, A. (2004). For better or for worse: Default effects and 401 (k) savings behavior Perspectives on the Economics of Aging (pp. 81-126): University of Chicago Press.

[21] Daniel, K., Hirshleifer, D., \& Subrahmanyam, A. (1998). Investor psychology and security market under-and overreactions. the Journal of Finance, 53(6), 1839-1885.
[22] De Bondt, W. F., \& Thaler, R. (1985). Does the stock market overreact? The Journal of finance, 40(3), 793-805.

[23] De Vries, A., Erasmus, P. D., \& Gerber, C. (2017). The familiar versus the unfamiliar: Familiarity bias amongst individual investors. Acta Commercii, 17(1), 1-10.

[24] Fox, C. R., \& Tversky, A. (1995). Ambiguity aversion and comparative ignorance. The quarterly journal of economics, 110(3), 585-603.

[25] Garang, M. (2016). The Effect Of Financial Literacy On Investment Decisions In The Juba City South Sudan. University of Nairobi.

[26] Gervais, S., \& Odean, T. (2001). Learning to be overconfident. The Review of Financial Studies, 14(1), 1-27.

[27] Giesler, M., \& Veresiu, E. (2014). Creating the responsible consumer: Moralistic governance regimes and consumer subjectivity. Journal of Consumer Research, 41(3), 840-857.

[28] Hameed, W. U., Basheer, M. F., Iqbal, J., Anwar, A., \& Ahmad, H. K. (2018). Determinants of Firm's open innovation performance and the role of $R \& D$ department: an empirical evidence from Malaysian SME's. Journal of Global Entrepreneurship Research, 8(1), 29. doi: https://doi.org/10.1186/s40497-018-01128

[29] Heath, C., \& Tversky, A. (1991). Preference and belief: Ambiguity and competence in choice under uncertainty. Journal of risk and uncertainty, 4(1), 5-28.

[30] Hirshleifer, D. (2001). Investor psychology and asset pricing. The journal of Finance, 56(4), 1533-1597.

[31] Huberman, G. (2001). Familiarity breeds investment. The Review of Financial Studies, 14(3), 659-680.

[32] Lee, Y.-T., Liu, Y.-J., Roll, R., \& Subrahmanyam, A. (2004). Order imbalances and market efficiency: Evidence from the Taiwan Stock Exchange. 
Journal of Financial and Quantitative Analysis, 39(2), 327-341.

[33] Lintner, J. (1975). The valuation of risk assets and the selection of risky investments in stock portfolios and capital budgets Stochastic optimization models in finance (pp. 131-155): Elsevier.

[34] Majoch, A. A., Hoepner, A. G., \& Hebb, T. (2017). Sources of stakeholder salience in the responsible investment movement: why do investors sign the principles for responsible investment? Journal of Business Ethics, 140(4), 723-741.

[35] Mayfield, C., Perdue, G., \& Wooten, K. (2008). Investment management and personality type. Financial services review, 17(3), 219-236.

[36] Merton, R. C. (1987). A simple model of capital market equilibrium with incomplete information.

[37] Mishra, S. (2014). Decision-making under risk: Integrating perspectives from biology, economics, and psychology. Personality and Social Psychology Review, 18(3), 280307.

[38] Montier, J., \& Strategy, G. E. (2002). Applied Behavioural Finance: Insights into irrational minds and market. Unpublished manuscript.

[39] Odean, T. (1998). Volume, volatility, price, and profit when all traders are above average. The journal of finance, 53(6), 1887-1934.

[40] Pompian, M. M. (2008). Using behavioral investor types to build better relationships with your clients. Journal of Financial Planning, 21(10), 64-76.

[41] Razzaq, S., Maqbool, N., \& Hameed, W. U. (2019). Factors Effecting The Elasticity Of Micro Credit Demand In Southern Punjab, Pakistan. International Journal of Social Sciences and Economic Review, 1(2), 4653. doi: https://doi.org/10.36923/ijsser.v1i2.34

[42] Sharpe, W. F. (1964). Capital asset prices: A theory of market equilibrium under conditions of risk. The journal of finance, 19(3), 425-442.

[43] Shiloh, S., Salton, E., \& Sharabi, D. (2002). Individual differences in rational and intuitive thinking styles as predictors of heuristic responses and framing effects. Personality and Individual Differences, 32(3), 415-429.

[44] Thaler, R. H., \& Sunstein, C. R. (2009). Nudge: Improving decisions about health, wealth, and happiness: Penguin.

[45] Tversky, A., \& Kahneman, D. (1974). Judgment under uncertainty: Heuristics and biases. science, 185(4157), 1124-1131.

[46] Ul-Hameed, W., Mohammad, H., \& Shahar, H. (2018). Microfinance institute's non-financial services and womenempowerment: The role of vulnerability. Management Science Letters, 8(10), 11031116. doi: https://doi.org/10.5267/j.msl.2018.7.001

[47] Van Rooij, M., Lusardi, A., \& Alessie, R. (2011). Financial literacy and stock market participation. Journal of Financial Economics, 101(2), 449-472.

[48] Wang, M., Keller, C., \& Siegrist, M. (2011). The less You know, the more You are afraid of - A survey on risk perceptions of investment products. Journal of Behavioral Finance, 12(1), 9-19.

[49] Yalcin, K. C., Tatoglu, E., \& Zaim, S. (2016). Developing an instrument for measuring the effects of heuristics on investment decisions. Kybernetes. 